RESEARCH ARTICLE

\title{
ANTIMICROBIAL ACTIVITY OF FRUITS OF PRUNUS ARMENIACA (L.)
}

\author{
${ }^{1}$ Sehgal Jaya*, ${ }^{2}$ Lamba HS \\ ${ }^{1}$ Research Scholar,Bhagwant University,Ajmer (Rajasthan) \\ ${ }^{2}$ H.R.Institute of Pharmacy,Ghaziabad,(U.P.) \\ *Corresponding Authors Email ID: jayasharma36@gmail.com
}

Received 28 May 2012; Review Completed 13 July 2012; Accepted 13 July 2012, Available online 15 July 2012

\begin{abstract}
Prunus armeniaca (L.) is known as apricot. It belongs to family Rosaceae. It is a hard tree bearing stone fruit which is closely related to peach. It is found in Asia, Europe, North America, China, Maharashtra, and Himachal Pradesh.

The present study describes the antimicrobial activity of ethanolic and aqueous extracts of fruits of Prunus armeniaca (L.) These activities were tested against human pathogenic microorganisms using disc diffusion method and zone of inhibition of each active extract was determined. The most effective antibacterial activity was observed in the ethanolic extract of fruits against Staphylococcus aureus and Bacillus subtilis. Additionally, the ethanolic extract was effective against Proteus vulgaris and Escherichia coli. Significant activity against Candida albicans was also observed with the ethanolic extract. The ethanolic extract showed more significant antimicrobial activity as compared to aqueous extract.

Key Words: Prunus, armeniaca, rosaceae, antimicrobial
\end{abstract}

\section{INTRODUCTION:}

A large number of medicinal plants are claimed to be useful in bacterial and fungal diseases in all traditional system of medicine and folklore. While these plants are require proving scientifically. The apricot (Prunus armeniaca L.) is a member of the Rosaceae family ${ }^{1,2}$. Apricot fruit being a rich source of vitamins \& minerals is one of the most familiar crops worlds wide. Apricot trees are not ubiquitous since they can only grow in certain regions where the environmental conditions are favourable. In general Prunus armeniaca (L.) is used in folk medicine in the treatment of skin diseases ${ }^{3,4}$ \& parasitic diseases ${ }^{5,6}$. As a part of search for new biological activity of a plant extracts preliminary bioscreening ${ }^{7}$ were performed to evaluate the antibacterial and antifungal activity of ethanolic and aqueous extracts of Prunus armeniaca (L.).

\section{MATERIALS AND METHODS}

The plant Prunus armeniaca (L.) has been collected from private farm of Simla, district of Himachal Pradesh; India. The plant was identified at Plant Anatomy Research Center, West Tambaram, Chennai (PARC/2009/478).

\section{ANTIB ACTERIAL ACTIVITY ${ }^{8,9}$ :}

\section{Preparation of culture media: ${ }^{10}$}

Mueller Hinton Agar:

$\begin{array}{lll}\text { Beef, Infusion Form } & - & 300 \mathrm{~g} \mathrm{~m} \\ \text { Casein Acid Hydrolysate } & - & 17.50 \mathrm{~g} \mathrm{~m} \\ \text { Starch } & - & 1.50 \mathrm{~g} \mathrm{~m} \\ \text { Agar } & - & 17.00 \mathrm{gm} \\ \text { Distilled water } & - & \text { q.s.to make } 1000 \mathrm{ml}\end{array}$

Beef extract, Casein acid Hydrolysate, starch and agar were mixed with $800 \mathrm{ml}$ of distilled water and digested for an hour on water bath. The $\mathrm{pH}$ was adjusted to 7.4. Volume was adjusted to $1000 \mathrm{ml}$ with distilled water. It was then again digested on autoclaving at $121^{\circ} \mathrm{C}, 15 \mathrm{lbs}$ pressure for 20 minutes, cooled and stored in a refrigerator for over night.

\section{Preparation of standard discs:}

Commercially available standard discs (Hi Media Company) were taken as a standard drug.

\section{Preparation of sample:}

From stock solution of test extracts different concentration were prepared for performing antibacterial activity. The dilute extracts were stored in a sterile container and kept in a refrigerator.

\section{Method of inoculation in solid media:}

A platinum loop was well sterilized by keeping it vertically on a flame and it was made red hot and allowed to cool. The loop was touched with well-mixed specimens and rubbed on one side of dry media in little area (A). The loop was again sterilized and plate was rotated for $90^{\circ}$. The loop was rubbed 3-4 times on media of previously inoculated side (A) and little part of non-inoculated media was (B). Again the plate was rotated and above process was repeated.

\section{Screening of antibacterial activity ${ }^{11,12}$ :}

\section{Cup plate method:}

Micro- wells were made on culture media in $6 \mathrm{~mm}$ in diameter with the help of gel puncture machine. The micro- wells were filled with $100 \mu \mathrm{l}$ from diffe rent concentration of ethanolic and aqueous extracts. Standard disc (Ciprofloxacin) was also impregnated on the medium. The Petri dishes used for antibacterial screening were incubated at $37^{0} \mathrm{C}$ for $24-48$ hours. The activity was measured in terms of diameter of zone of inhibition appearing around the micro -wells. 
Table 1: Antibacterial effect of various extracts of fruits of prunus armeniaca (1.) on various pathogenic microorganisms

\begin{tabular}{|c|c|c|c|c|c|c|c|}
\hline \multirow[b]{2}{*}{ Microorg anisms } & \multicolumn{7}{|c|}{ ZONE OF INHIB ITION (mm) } \\
\hline & $\begin{array}{l}\text { Ethanolic } \\
\text { Extract } \\
\text { 4mg/ml }\end{array}$ & $\begin{array}{l}\text { Aque ous } \\
\text { Extract } \\
4 \mathrm{mg} / \mathrm{ml}\end{array}$ & $\begin{array}{l}\text { Ethanolic } \\
\text { Extract } \\
2 \mathrm{mg} / \mathrm{ml}\end{array}$ & $\begin{array}{l}\text { Aque ous } \\
\text { Extract } \\
2 \mathrm{mg} / \mathrm{ml}\end{array}$ & $\begin{array}{l}\text { Ethanolic } \\
\text { Extract } \\
1 \mathrm{mg} / \mathrm{ml}\end{array}$ & $\begin{array}{l}\text { Aque ous } \\
\text { Extract } \\
1 \mathrm{mg} / \mathrm{ml}\end{array}$ & 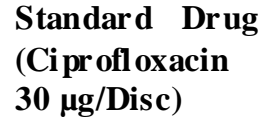 \\
\hline Escherichia coli & 20 & 18 & 12 & 12 & 00 & 00 & 30 \\
\hline Staphylococcus aureus & 27 & 22 & 30 & 24 & 40 & 27 & 15 \\
\hline Proteus vulgaris & 30 & 21 & 16 & 06 & 06 & 00 & 28 \\
\hline Bacillus subtilis & 44 & 40 & 30 & 18 & 22 & 16 & 30 \\
\hline
\end{tabular}

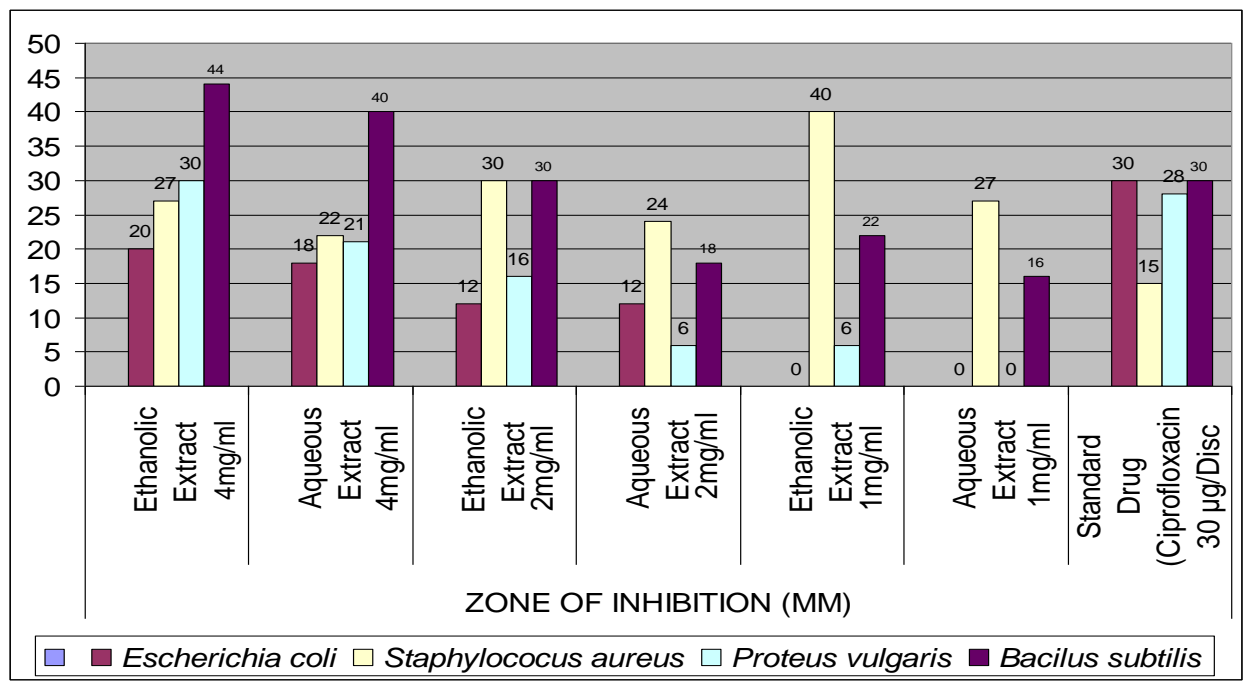

Figure 1: Graphical representation of antibacterial acti vity of various extracts of fruits of Prunus armeniaca (l.)

\section{ANTIFUNGAL ACTIVITY:}

\section{Preparation of culture media: ${ }^{10}$}

Sabouraud's dextrose broth:

$\begin{array}{lll}\text { Dextrose } & - & 4.0 \mathrm{gm} \\ \text { Peptone } & - & 1.0 \mathrm{gm} \\ \text { Agar } & - & 1.50 \mathrm{~g} \mathrm{~m} \\ \text { Chloramphenicol } & - & 5.0 \mathrm{mg} \\ \text { Distilled water } & - & \text { q.s.to make } 1000 \mathrm{ml}\end{array}$

Dextrose, peptone, agar and Chloramphenicol were mixed with $800 \mathrm{ml}$ of distilled water and digested for an hour on water bath. The $\mathrm{pH}$ was adjusted to 5.4-5.8. Volume was adjusted to $1000 \mathrm{ml}$ with distilled water. It was then again digested on autoclaving at $121^{\circ} \mathrm{C}, 15 \mathrm{lbs}$ pressure for 20 minutes, cooled and stored in a refrigerator for 3-5 days.

\section{Preparation of standard discs:}

Commercially available standard discs (Hi Media Company) were taken as a standard drug.

\section{Preparation of sample:}

From stock solution of test extracts of concentration 200 $\mu \mathrm{g} / \mathrm{ml}$ were prepared for performing antifungal activity. The dilute extracts were stored in a sterile container and kept in a refrigerator.

\section{Method of inocul ation in solid media:}

A platinum loop was well sterilized by keeping it vertically on a flame and it was made red hot and allowed to cool. The loop was touched with well-mixed specimens and rubbed on one side of dry media in little area (A). The loop was again sterilized and plate was rotated for $90^{\circ}$. The loop was rubbed 3-4 times on media of previously inoculated side (A) and part of non-inoculated media was (B). Again the plate was rotated and above process was repeated.

Screening of antifungal activity ${ }^{11,12:}$

Cup plate method ${ }^{13,14}$ :

Micro- wells were made on culture media in $6 \mathrm{~mm}$ in diameter with the help of gel puncture machine. The micro- wells were filled with $100 \mu \mathrm{l}$ by $200 \mu \mathrm{g} / \mathrm{ml}$ of ethanolic and aqueous extracts. Standards disc (Amphoteric in B $50 \mu \mathrm{g} /$ disc) was also impregnated on the medium. The Petri dishes used for antifungal screening were incubated at $37^{\circ} \mathrm{C}$ for $24-48$ hours. The activity was measured in terms of diameter of zone of inhibition appearing around the micro -wells.

Results of screening of antifungal activity with different extracts of Prunus armeniaca (L.) are given in the Table No. 2. 
Table 2: Antifungal effects of various extracts of fruits of Prunus armeniaca (L.) on various pathogenic microorganisms

\begin{tabular}{|l|c|c|c|}
\hline \multirow{2}{*}{ Micro-organisms } & \multicolumn{2}{|c|}{ Zone of Inhi bition (mm) } \\
\cline { 2 - 4 } & $\begin{array}{c}\text { Ethanolic Extract 200 } \\
\boldsymbol{\mu} \mathbf{g} / \mathbf{m l}\end{array}$ & $\begin{array}{c}\text { Aqueous Extract } \\
\mathbf{2 0 0} \boldsymbol{\mu g} / \mathbf{m l}\end{array}$ & $\begin{array}{c}\text { Standard Drug (Amphotericin B) } \\
\mathbf{5 0} \boldsymbol{\mu g} / \mathbf{D i s c}\end{array}$ \\
\hline Candida albicans 32354 - B311 & 08 & 00 & 10 \\
\hline Aspergillus niger 38857 (IFO4407) & 00 & 00 & 12 \\
\hline
\end{tabular}

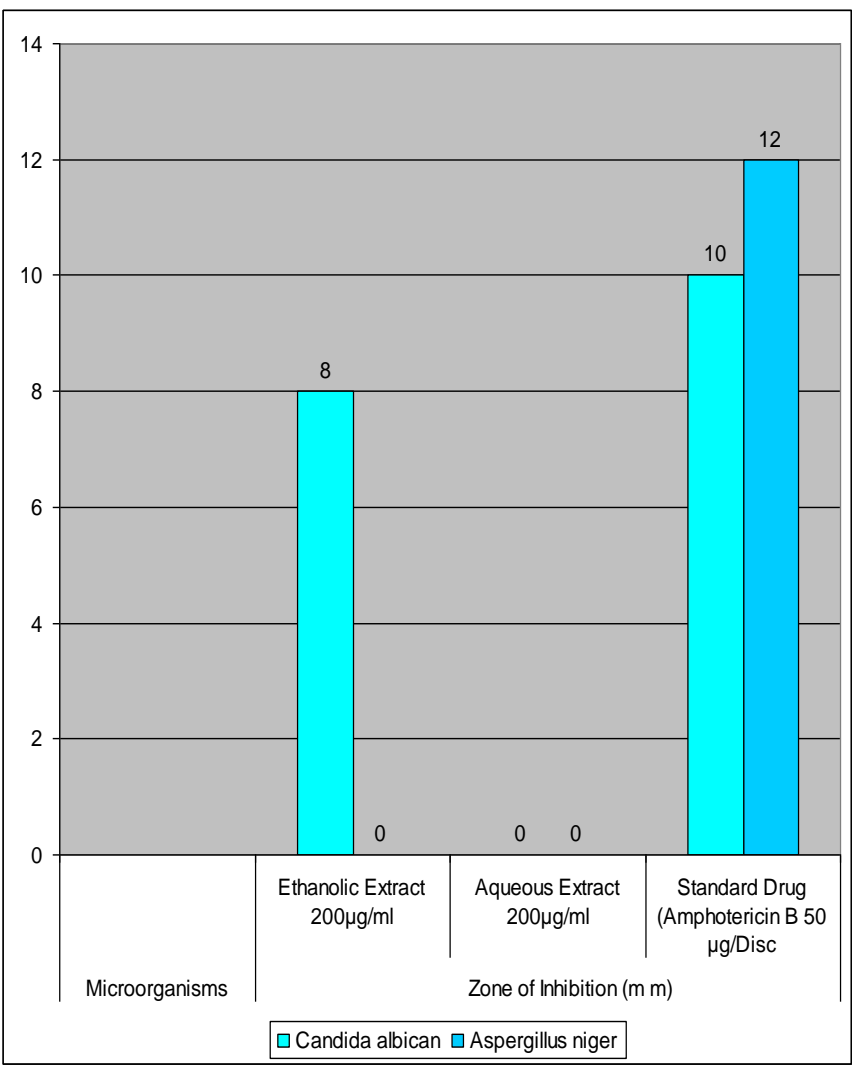

Figure 2: Graphical representation of antifungal activity of various extracts of fruits of Prunus armeniaca (l.)

\section{RES ULTS AND DISCUSSION}

Antibacterial activity of ethanolic and aqueous extracts of Prunus armeniaca (L.), were investigated.

Ethanolic and aqueous extracts of Prunus armeniaca (L.) showed the antibacterial activity against Escherichia coli, Staphylococcus aureus, Proteus vulgaris and Bacillus subtilis.

For Escherichia coli: Ethanolic extract at different concentrations $(400,200$ and $100 \mu \mathrm{g} / \mathrm{ml})$ showed the zone of inhibition $20 \mathrm{~mm}, 12 \mathrm{~mm}, 00 \mathrm{~mm}$ respectively. Aqueous extract at different concentrations (400, 200 and 100 $\mu \mathrm{g} / \mathrm{ml})$ showed the zone of inhibition 18, 12, $00(\mathrm{~mm})$ respectively as compared to standard drug (Ciprofloxacin $30 \mu \mathrm{g} /$ disc) $30 \mathrm{~mm}$.

For Staphylococcus aureus: Ethanolic extract at different concentrations $(400,200$ and $100 \mu \mathrm{g} / \mathrm{ml})$ showed the zone of inhibition 27, 30,40( $\mathrm{mm})$ respectively. Aqueous extract at different concentrations (400, 200 and $100 \mu \mathrm{g} / \mathrm{ml}$ ) showed the zone of inhibition 22, 24, $27(\mathrm{~mm})$ respectively as compared to standard drug (Ciprofloxacin $30 \mu \mathrm{g} / \mathrm{disc}$ ) $15 \mathrm{~mm}$.

For Proteus vulgaris: Ethanolic extract at different concentrations $(400,200$ and $100 \mu \mathrm{g} / \mathrm{ml})$ showed the zone of inhibition $30 \mathrm{~mm}, 16 \mathrm{~mm}, 06 \mathrm{~mm}$ respectively. Aqueous extract at different concentrations $(400,200$ and 100 $\mu \mathrm{g} / \mathrm{ml})$ showed the zone of inhibition $21,06,00(\mathrm{~mm})$ respectively as compared to standard drug (Ciprofloxacin $30 \mu \mathrm{g} /$ disc) $28 \mathrm{~mm}$.

For Bacillus subtilis: Ethanolic extract at different concentrations $(400,200$ and $100 \mu \mathrm{g} / \mathrm{ml})$ showed the zone of inhibition $44 \mathrm{~mm}, 30 \mathrm{~mm}, 22 \mathrm{~mm}$ respectively. Aqueous extract at different concentrations (400, 200 and 100 $\mu \mathrm{g} / \mathrm{ml})$ showed the zone of inhibition 40, 18, 16(mm) respectively as compared to standard drug (Ciprofloxacin $30 \mu \mathrm{g} / \mathrm{disc}) 30 \mathrm{~mm}$.

\section{Antifung al Activity:}

Antifungal activity of ethanolic and aqueous extracts of Prunus armeniaca (L.), were investigated.

For Candida albican: Ethanolic extract at concentration (200 $\mu \mathrm{g} / \mathrm{ml}$ ) showed the zone of inhibition $08 \mathrm{~mm}$. Aqueous extract at concentration $(200 \mu \mathrm{g} / \mathrm{ml})$ showed the zone of inhibition $00 \mathrm{~mm}$ as compared to standard drug (Amphoteric in B $50 \mu \mathrm{g} / \mathrm{disc}$ ) $10 \mathrm{~mm}$.

For Aspergillus niger: Both ethanolic and aqueous extracts at concentration $(200 \mu \mathrm{g} / \mathrm{ml})$ showed no antifungal activity. Only ethanolic extract of Prunus armeniaca (L.) showed the antifungal activity against Candida albican.

\section{CONCLUSION}

The antibacterial studies on both ethanolic and aqueous extracts $(400 \mu \mathrm{g} / \mathrm{ml})$ showed significant antibacterial activity against Staphylococcus aureus, Bacillus subtilis and Proteus vulgaris as compared to standard drug (Ciprofloxacin $30 \mu \mathrm{g} / \mathrm{disc}$ ). Ethanolic extract showed more significant antibacterial activity as compared to aqueous extract.

The antifungal studies on ethanolic extract $(200 \mu \mathrm{g} / \mathrm{ml})$ of the fruit showed significant effect against Candida albican as compared to standard drug (Amphotericin B 50 $\mu \mathrm{g} / \mathrm{disc})$. Ethanolic extract showed significant antifungal activity where as aqueous extract showed no activity.

\section{ACKNOWLEDGEMENT}

The authors are sincerely grateful to Plant Anatomy Research Center, West Tambaram, Chennai for its cooperation in the identification and providing some useful information about the plant of interest. 
1. Chopra, R.N., Nay ar, L. and Chopra I.C. Glossary of Indian Medicinal Plants. Elsevier CSIR New Delhi, 204,1956.

2. "The Wealth of India", 1969, A Dictionary of Indian Raw Materials and industrial products. Council of Scientific and Industrial Research, New Delhi, India 1969, 8, 256.

3. Sharma, S.R., Dwivedi, S.K, Swarup, D, Journal of Ethno pharmacology, 1997, 58, 39-44.

4. Nagarajan, G.R. and Parmar, V.S. Planta Medica, 1977,32, 50 .

5. Lily, M.P. and Metzger, J. (1980) Medicinal Plants of East and Southeast Asia; attributed properties and uses. The MIT press, Cambridge Massachusetts, 344.

6. Gupta, D. R. and Bahar, A., Asplenetin, a flavone and its, Glycoside from Launaea asplenifolia. Phytochemistry., 24,873-875(1985).

7. Marie, B., Manual of Clinical Microbiology. Section: Aerobic bacteria. 4th edition, American Society for Microbiology. Washington D.C. (1985).
8. Ahmed, R., Rashid, F., Bibi, N., Kazmi, S. U., and Ansar, N., Phy tochemical studies on Prunus Armeniaca and antibacterial effects of fruit extracts., J. Trop. Med. Plants. 5, 37- 41 (2004).

9. Baquar, S. R., Medicinal and Poisonous Plants of Pakistan. Printas Karachi, Pakistan, p.364 (1989).

10. Godkar Praful B., Godkar Darshan P., Text Book of Medical Laboratory Technology, 2nd Ed, Bhalani Publishing House, India.540.

11. Panda, H. (2004) Herbal Foods and its Medicinal Values. National Institute of Industrial research, Kamal Nagar, Delhi-110007, India, 182.

12. Rangari, V., Pharmacognosy and phytochemistry, 2002, 130-134.

13. Madhu C, Divakar, Plant Drug Evaluation, $2^{\text {nd }} E d, 2002$, C.D. Remedies Publication; 49-52, 84-89.

14. YogaNarasimhan, S.N.2000, Medicinal Plants of India, Vol. 2, Tamilnadu, Regional Research Institute (Ay.) Bangalore, India, 715. 